\title{
Route of birth delivery preferred by mothers and their motivations
}

\author{
Via de parto preferida por puérperas e suas motivações \\ Vía de nacimiento elegida por puérperas y sus motivaciones
}

Fernanda Kottwitz ${ }^{1}$ Helga Geremias Gouveia ${ }^{2}$ Annelise de Carvalho Gonçalves ${ }^{2}$

1. Hospital Sofia Feldman. Belo Horizonte, MG, Brazil.

2. Universidade Federal do Rio Grande do Sul. Porto Alegre, RS, Brazil.
Autor correspondente:

Fernanda Kottwitz.

E-mail: nandakwz@gmail.com

Submitted on $07 / 03 / 2017$

Accepted on 09/09/2017.

DOI: 10.1590/2177-9465-EAN-2017-0013

\begin{abstract}
Objective: Identify the route of birth delivery preferred by mothers and their motivations. Method: Cross-sectional study with 361 mothers from a university hospital. Data were obtained using a structured questionnaire from February to April 2013. Descriptive analysis was performed and the Chi-square test was used to verify association among the variables. Results: $77.6 \%$ of the women preferred vaginal delivery and the reason reported by $81.8 \%$ of them was easier recovery postpartum; $20.5 \%$ believed they took part in the decision-making concerning the type of delivery; $64.5 \%$ believed the type of delivery they experienced did not involve risk for themselves, while $21.9 \%$ believed it involved risk for the newborn. Statistical association was found between number of deliveries and type of previous delivery with the preferred route of delivery. Conclusion: Women did not have adequate knowledge regarding the risks and benefits of different types of delivery and for this reason were not empowered to exert their autonomy in regard to this decision.
\end{abstract}

Keywords: Choice Behavior; Natural Childbirth; Cesarean Section; Patient Preference.

\section{Resumo}

Objetivo: Conhecer a via de parto preferida pelas puérperas e suas motivações. Método: Estudo transversal, com 361 puérperas de um hospital universitário. Os dados foram obtidos por meio de questionário estruturado, de fevereiro a abril de 2013. Realizou-se análise descritiva e, para a verificação da associação entre as variáveis, o Teste de Quiquadrado. Resultados: 77,6\% das mulheres preferiram o parto vaginal, e o motivo, para 81,8\% destas, foi melhor recuperação pós-parto; $20,5 \%$ acreditaram ter participado da decisão sobre o tipo de parto; $64,5 \%$ acreditavam que o parto ao qual foram submetidas não envolveu riscos para si e $21,9 \%$ acharam que envolvia riscos para o recém-nascido. Houve associação estatística entre paridade e tipo de parto anterior com a via de parto preferida. Conclusão: As mulheres não demonstraram conhecimento adequado sobre os riscos e benefícios dos tipos de parto e, por isso, acredita-se não estarem empoderadas para exercer sua autonomia nessa decisão.

Palavras-chave: Comportamento de Escolha; Parto Normal; Cesárea; Preferência do Paciente.

\section{Resumen}

Objetivo: Conocer la preferencia y la motivación de las mujeres en cuanto a vía de parto. Método: Estudio transversal con 361 puérperas de un hospital universitario. Datos obtenidos entre febrero y abril de 2013 a partir de cuestionario estructurado. Se realizó un análisis descriptivo y, para verificación de las variables, el Test Chi-Cuadrado. Resultados: El 77,6\% de las mujeres prefirieron el parto vaginal, el $81,8 \%$ de estas por la recuperación postparto. El 20,5\% creen haber participado en la decisión del tipo de parto. El $64,5 \%$ creían que el parto al cual fueron sometidas no involucraba riesgos para ellas y $21,9 \%$ pensaron que implicaba riesgos para el recién nacido. Hubo asociación estadística positiva entre paridad y tipo de parto anterior con la vía preferida. Conclusión: Las mujeres no tenían conocimiento adecuado sobre riesgos y beneficios de los tipos de parto y, por ello, no creen estar empoderadas para ejercer su autonomía.

Palabras clave: Conducta de Elección; Parto Normal; Cesárea; Preferencia del Paciente. 


\section{INTRODUCTION}

Historically, childbirth is a natural event and a mobilizing phenomenon that involves countless cultural and social meanings, which in turn influence the decision-making process concerning the route of birth delivery. Childbirth care has changed considerably and physiological birth gave way to increasingly medicalized and interventionist care..$^{1,2}$

This medicalized process was initiated in the $19^{\text {th }}$ century and intensified in the $20^{\text {th }}$ century, a time when surgical deliveries became popular and were increasingly used to improve care and maternal and neonatal outcomes. Nonetheless, it is currently used to an excessive degree. ${ }^{2}$ The biomedical model has contributed to a situation in which women have gradually lost their autonomy and their protagonist role at the time of birth, increasing asymmetry between professionals and patients. ${ }^{3,1}$

One reflection of medicalization is the increased number of $\mathrm{C}$-sections verified worldwide; it is the most common surgery performed among women. ${ }^{4}$ Brazil presents one of the highest rates of C-sections, which represents a real epidemic. In 2015, the country reached a rate of $55.5 \% \mathrm{C}$-sections for all births. The southern region of Brazil presented an index of $60.54 \%$ and in Rio Grande do Sul, the state where this study was conducted, this index was $64.4 \%,{ }^{5}$ i.e., far beyond the $15 \%$ C-section-rate recommended by the World Health Organization (WHO) and the Ministry of Health $(\mathrm{MH}){ }^{6}$

Currently, many questions have arisen from the care provided to pregnant women concerning the effects of medicalization on labor and childbirth. ${ }^{2}$ These questions have lead to a search for alternatives with the objective of decreasing the number of surgical deliveries and unnecessary interventions during birth, seeking support for evidence-based care, in order to decrease asymmetry between professionals and patients. ${ }^{7}$

There is a urgent need to change the educational approach of both healthcare workers and women of reproductive age beyond routes of delivery, and consider the right of women to choose and acknowledge their political-social role within and outside the hospital. ${ }^{7}$ It is necessary to reconsider the participation and autonomy of pregnant women when deciding on the outcomes of their pregnancy.

It is imperative that healthcare professionals work to strengthen the autonomy of women. Empowering women is to provide them knowledge and support them so that they become more aware of their rights as citizens. Such empowerment enlarges their knowledge concerning their social and health situation, reinforcing knowledge regarding their role in society, bringing about their ability to change power relationships and make conscious choices regarding themselves. ${ }^{8}$

Expectant women make choices regarding routes of delivery based on self-knowledge, previous experiences, knowledge they exchange with the community in which they live, their expectations, and access they have to information during pregnancy. Obstetrical nurses are potential facilitators in terms of educational and health actions to empower women during the pregnancy-puerperal cycle, strengthening their participation in decision-making regarding childbirth.

Based on the previous discussion, this study is intended to identify the route of delivery that is preferred by women, as well as their motivations; identify the knowledge they have concerning the risks imposed on themselves and their babies by the route of delivery taken; identify whether they took part in decision-making concerning route of delivery; and verify potential association of sociodemographic and obstetrical characteristics of women with the preferred route of birth delivery. Data obtained in this study can support the care provided by healthcare workers during prenatal care based on the individual expectations and needs of pregnant women. Additionally, identifying the motivations and insecurities of women regarding childbirth enables the development of alternatives to demystify and resignify birth so that women are able to exercise their autonomy and discuss with the healthcare staff what the best outcome for their pregnancies would be, consequently decreasing unnecessary obstetrical interventions.

\section{METHOD}

This cross-sectional study was conducted in the Obstetrical Unit of a university hospital located in the south of Brazil, from February to April 2013.

This paper is part of a larger study titled: "Factors associated with $\mathrm{C}$-sections in a university hospital". The sample size was based on the number of deliveries and the rate of $\mathrm{C}$-sections performed in 2001, considering an absolute 5\% margin of error and confidence interval of $95 \%$. A total of 359 mothers were necessary to compose the study sample, while 361 mothers who delivered their babies in the Obstetrical Center of the aforementioned institution were interviewed. Those unable to answer the questionnaire due to an unsuitable psychological condition, who experienced fetal death, whose newborns weighed less than $\mathbf{5 0 0}$ grams or had a gestational age equal to or below 22 weeks, were not invited to participate in the study.

The Event Report form of the restricted area of the Obstetrical Center was used to collect data along with the patients' medical files and those of their newborns, prenatal care files, and a structured questionnaire. The questionnaire was applied daily to mothers in the first 12 hours after delivery.

The SPSS version 18 was used to analyze data, as were descriptive statistics. The Chi-square test was used to verify association among variables. The results were considered statistically significant when $p \leq 0.05$.

The mothers received clarification regarding this study's objectives and those who consented, signed free and informed consent forms. The legal guardians of minors also received clarification and signed informed consent forms. 
The study was approved by the Institutional Review Boards at the hospital (report No. 120466) and at the Federal University of Rio Grande do Sul, School of Nursing.

\section{RESULTS}

This study sample was composed of 361 mothers, most $(77.6 \%)$ of whom desired vaginal delivery for their current pregnancy (Table 1).

Table 1. Distribution of mothers according to the type of delivery desired. Porto Alegre, RS, Brazil 2015. ( $N=361)$.

\begin{tabular}{lcc}
\hline Type of delivery desired & $\mathbf{N}$ & $\%$ \\
\hline Vaginal & 280 & 77.6 \\
\hline C-section & 77 & 21.3 \\
Did not know & 04 & 1.1 \\
\hline Total & 361 & 100.0 \\
\hline
\end{tabular}

The reason explaining the women's preferences (Table 2), among those who preferred a C-section, was "not feeling pain" (74.0\%), while "easier recovery postpartum" (81.8\%) was the motivation among those who preferred a vaginal delivery.

In regard to the participation of women in decision-making concerning the type of delivery (Table 3): 74 women (20.5\%) reported they were asked about what was their preferred route of delivery and took part in the decision-making. Note, however, that 260 women $(72.0 \%)$ were not even asked about their preferences regarding the type of delivery.

Table 4 presents data concerning the knowledge of women regarding the risks the type of delivery imposed on themselves and their newborns. Most women considered that the type of delivery, whether $\mathrm{C}$-section or vaginal, does not impose any risk on their health or that of their babies (64.8\% and $67.9 \%)$.

In regard to the risks, $21.9 \%$ of the mothers believed that the type of delivery they experienced imposed risk on the baby's health. Note that most of these women had experienced a vaginal birth. In regard to the risks imposed on their own health, $22.2 \%$ believed that the type of delivery they experienced presented risks, most of whom had a C-section (Table 4).
Table 2. Distribution of mothers according to their motivations behind choices of delivery. Porto Alegre, RN, Brazil 2015. ( $N=357)^{*}$.

\begin{tabular}{lcc}
\hline $\begin{array}{l}\text { Reasons explaining preference for type of } \\
\text { delivery }\end{array}$ & N & $\%$ \\
\hline C-sections & 57 & 74.0 \\
\hline Not feeling pain & 10 & 13.0 \\
Previous positive experience & 03 & 3.9 \\
Tubal ligation & 01 & 1.3 \\
Did not know & 06 & 7.8 \\
Other & & \\
\hline Vaginal delivery & 229 & 81.8 \\
\hline Easier recovery postpartum & 17 & 6.0 \\
Safer & 08 & 2.9 \\
Benefits for mother and newborn & 07 & 2.5 \\
Active participation of women during delivery & 07 & 2.5 \\
Fear of scar & 04 & 1.4 \\
Previous positive experience & 08 & 2.9 \\
\hline Others &
\end{tabular}

The risks most frequently reported by the women, regardless of the type of delivery, were infection $(26.2 \%)$ and bleeding $(13.8 \%)$, while the risks imposed on the baby that were most frequently reported included delaying the time of birth (15.2\%) and injuring the baby (13.9\%).

The mothers' characteristics and obstetrical history, as well as associations with the type of delivery they wished, are presented in Table 5. Most women were aged between 16 and 34 years old $(85.7 \%)$, had attended more than eight years of school (52.4\%);, and had a family income of up two times the minimum wage $(67.8 \%)$. In regard to their obstetrical history, most had two or more pregnancies (63.9\%) and most who had a previous delivery delivered vaginally $(74.1 \%)$. The variables analyzed reveal that the number of pregnancies and type of previous delivery were statistically associated with the type of delivery women wished to have.

Table 3. Distribution of women according to their participation in decision-making regarding current birth. Porto Alegre, RS, Brazil 2015. ( $\mathrm{N}=361)$.

\begin{tabular}{lccccc} 
& & \multicolumn{2}{c}{ regarding the type of your current delivery? } \\
& & Yes & No & Did not know \\
\hline Were you asked what type of delivery you wished? & Yes & 74 & 26 & 01 & 01 \\
Notal & No & 62 & 198 & 00 & 01 \\
\hline
\end{tabular}


Table 4. Distribution of women according to the risks imposed on themselves and their newborns by the type of delivery they experienced. Porto Alegre, RS, Brazil 2015. ( $N=361)$

\begin{tabular}{lcccccc}
\hline & \multicolumn{2}{c}{ Vaginal } & \multicolumn{2}{c}{ C-section } & \multicolumn{2}{c}{ Total } \\
& $\mathbf{N}$ & $\%$ & $\mathbf{N}$ & $\%$ & $\mathbf{N}$ & $\%$ \\
\hline Risks to themselves & & & & & & \\
\hline Yes, I believe there are risks & 36 & 10.0 & 44 & 12.2 & 80 & 22.2 \\
I do not think there are risks & 174 & 48.2 & 59 & 16.3 & 234 & 64.5 \\
I do not know & 38 & 10.5 & 10 & 2.8 & 48 & 13.3 \\
\hline Risks for the newborn & & & & & & 79 \\
\hline Yes, I believe there are risks & 60 & 16.6 & 19 & 5.3 & 21.9 \\
I do not think there are risks & 161 & 44.6 & 84 & 23.3 & 245 & 67.9 \\
I do not know & 27 & 7.5 & 10 & 2.7 & 37 & 10.2 \\
\hline
\end{tabular}

Table 5. Distribution of women according to age, education, family income, obstetrical history, and previous deliveries, associated with the type of delivery desired. Porto Alegre, RS, Brazil 2015 ( $N=357$ )*

\begin{tabular}{|c|c|c|c|c|c|}
\hline \multirow{2}{*}{ Variable } & \multicolumn{2}{|c|}{ Vaginal delivery } & \multicolumn{2}{|c|}{ C-section } & \multirow{2}{*}{$p$ value } \\
\hline & $\mathbf{N}$ & $\%$ & $\mathbf{N}$ & $\%$ & \\
\hline Age & & & & & 0.328 \\
\hline$\leq 15$ years old & 07 & 2.0 & 00 & 0.0 & \\
\hline 16 to 34 years old & 240 & 67.2 & 66 & 18.5 & \\
\hline$\geq 35$ years old & 33 & 9.2 & 11 & 3.1 & \\
\hline Education & & & & & 0.295 \\
\hline$<8$ years of schooling & 83 & 23.2 & 16 & 4.5 & \\
\hline 8 years of schooling & 55 & 15.4 & 16 & 4.5 & \\
\hline$>8$ years of schooling & 142 & 39.8 & 45 & 12.6 & \\
\hline Family income & & & & & 0.815 \\
\hline One times the minimum wage or less & 93 & 26.1 & 22 & 6.2 & \\
\hline Two times the minimum wage & 100 & 28.0 & 27 & 7.5 & \\
\hline Three times the minimum wage & 69 & 19.3 & 22 & 6.2 & \\
\hline Do not know & 18 & 5.0 & 06 & 1.7 & \\
\hline Obstetrical history & & & & & 0.026 \\
\hline First pregnancy & 110 & 30.8 & 19 & 5.3 & \\
\hline Two or more pregnancies & 170 & 47.6 & 58 & 16.3 & \\
\hline Previous delivery & & & & & 0.000 \\
\hline No previous delivery & 17 & 7.5 & 02 & 3.4 & \\
\hline C-section & 20 & 8.8 & 33 & 56.9 & \\
\hline Vaginal & 114 & 50.0 & 14 & 24.1 & \\
\hline C-section + Vaginal & 19 & 8.2 & 09 & 15.5 & \\
\hline
\end{tabular}

* four women were unable to report the type of delivery they preferred. 


\section{DISCUSSION}

Studies, including this one, reveal women prefer vaginal delivery, ${ }^{9,10}$ which contradicts the high levels of $\mathrm{C}$-sections verified in all Brazilian regions. Note that, in recent years, none of the Brazilian regions met the WHO's recommendation of a maximum $15 \%$ C-sections. ${ }^{5}$

The main explanation provided by healthcare workers to justify the high rates of $\mathrm{C}$-sections in the country is that Brazilian women demand this type of delivery, ${ }^{11}$ though this and other recent studies ${ }^{9,10}$ report divergent data. The reasons accounting for the high prevalence of C-sections may be related to factors that influence the choices of women regarding the route of delivery, such as cultural values and economic factors, as well as information provided during the prenatal care. ${ }^{11}$ Additionally, the decisions of women regarding the route of delivery may be somewhat directed by physicians. The multicenter study, Born in Brazil, conducted with 24.940 women, reports that $66 \%$ preferred the vaginal route at the beginning of the pregnancy but $51.5 \%$ ended up having a $\mathrm{C}$-section, showing a significant decrease in the rate of vaginal deliveries when compared to the initial desires of women. ${ }^{9}$ Even though one cannot infer the reasons that led to this significant decrease in the number of vaginal births, when the preferences of women are compared with the real numbers of $\mathrm{C}$-sections, one can hypothesize that women were not truly autonomous during pregnancy and delivery.

When the perspectives of women regarding their preferred route of delivery are considered, studies, ${ }^{11,12}$ including this one, verify that vaginal delivery is chosen because its postpartum recovery is considered to be faster and easier. Another study also reports that women preferred vaginal birth because they believed that recovery after a C-section is slower and more painful. ${ }^{13}$ On the other hand, the main reason women chose a C-section, verified in this and in other studies, was due to fear of the pain caused by a vaginal birth ${ }^{12-14}$ and suffering experienced during vaginal labor. ${ }^{13}$

Suffering and fear were consistent results found regarding women's decisions on the route of delivery, which reveals there is a culture that has been established regarding a stereotype of painful labor. It is necessary to deconstruct this idea of suffering that is attached to labor in order to decrease the rates of $\mathrm{C}$-sections. Providing information to women regarding the functioning of their bodies, the physiology of labor, and the mechanisms of pain are important tools for resignifying vaginal delivery and empowering women. Note that the WHO recommends that non-pharmacological and pharmacological methods intended to alleviate pain be encouraged and widely disseminated in hospitals. ${ }^{15}$ Even though these methods are not available in all Brazilian maternity wards, these are resources that promote greater physical and emotional comfort for women during labor.
Prenatal care is also essential to providing education and information regarding these possibilities, as knowledge regarding these tools provided over the course of a pregnancy can contribute to decreasing the fear of women regarding childbirth and enable them to choose the route of delivery while free of any stereotype regarding suffering and fear. Prenatal care's educational role qualifies the knowledge of women and increases the number of alternatives they have. The role of an obstetrical nurse in the decision-making process of low-risk prenatal care is positive, as this is a specialized professional who can facilitate communication and deepen women's critical awareness and autonomy, ${ }^{8}$ empowering women and enabling them to become more able to protect themselves from obstetrical violence and interventions during the pregnancy-puerperal cycle.

Few women in this study reported having taken part in the decision-making process regarding the route of delivery, a fact also observed in professional practice, i.e., a certain type of delivery is often simply designated. Depending on the team providing care during labor and on the knowledge women have, the opinions of healthcare workers strongly influence the decisions of women and that of their families. Note that the fact women do not have proper knowledge regarding the physiology and duration of labor leads to even greater vulnerability to the decisions made by hospital staff and to a decreased power of choice.

The participation of women in decisions that concern their bodies during labor are closely related to the knowledge they have regarding how their bodies work and their understanding regarding the pregnancy-puerperal cycle. A recent review reports that extra-hospital practices and education enable the promotion of women's autonomy. These practices include prenatal care and the education of groups of pregnant women and mothers, resources that increase the possibility of developing a dialogue between professionals and expectant mothers, and, consequently, decrease asymmetry in the care process. ${ }^{7}$ Another study also reinforces the importance of information in the women's decision-making regarding their labor plan, in addition to the influence exerted by family and friends. ${ }^{16}$ Enabling women to express their knowledge and provide support for them to consciously construct their labor plan is an alternative that will empower and help them to assert their right to choose and play an active role at the time of delivery.

There are few studies assessing the participation of women in decision-making regarding the route of delivery, which hindered comparisons with other contexts. This fact also shows that there is low interest in listening to women in regard to their participation in decisions that concern their bodies. This limits not only this discussion but also shows women are seldom included in the decision-making processes that concern their pregnancies, and is directly linked to their satisfaction concerning the route of delivery and high rates of elective $\mathrm{C}$-sections. 
This study found there is a need for care and a desire to participate in the decision-making process that concerns the route of delivery ${ }^{17}$ Expanding the use of a labor plan in Brazil can contribute to women taking a more active role in the decisions that concern pregnancy and delivery. A labor plan is a tool that takes into account the desires and expectations of pregnant women, improving and promoting empathic communication between healthcare workers and women, so that information flows more fluidly and focuses on the women. ${ }^{17}$

This study also reveals that most women believed that the type of delivery they experienced did not involve risks to themselves or their babies. This is an alarming finding considering that women are unaware of potential risks imposed by the procedures, for both themselves and their babies. Data show that one woman dies every minute worldwide due to complications accruing from pregnancy or labor; ${ }^{18}$ i.e., there are risks inherent to the process, regardless of the type of delivery. Currently, the two main direct causes of maternal death in Brazil are hypertension and hemorrhaging. In 2012, these conditions respectively accounted for $20.2 \%$ and $11.9 \%$ of all maternal deaths. In that same year, the main cause of maternal deaths in the states of Paraná and Santa Catarina was hemorrhaging, with $18.6 \%$ and $15.6 \%$ respectively. ${ }^{6}$

If, on the one hand, a C-section is an excellent technology to decrease maternal and neonatal mortality and morbidity when employed within certain criteria, its indiscriminate use on the other hand, exerts a strong negative influence on these very same conditions, ${ }^{19,20}$ in addition to significantly increasing the risk of preterm and low-weight newborns. ${ }^{19}$ Brazil currently reports a significant number of preterm births. ${ }^{9}$ These data are confirmed in the Brazilian context, as the country presents a number of surgical deliveries in excess of WHO recommendations; nevertheless, maternal and neonatal deaths remain high. Note that, in 2011, neonatal mortality in Brazil reached 15.3/1,000 live births. ${ }^{20}$ Even though these rates have decreased ever since, they remain high. These numbers are closely linked to the care provided during pregnancy, labor and delivery. ${ }^{20}$

Note that the knowledge of women regarding the risks inherent to the route of delivery is seldom considered, as there are few papers addressing this topic, which restricts further discussion. This is a quantitative study and, for this reason, there is limited information regarding the guidance these mothers received during pregnancy and prenatal care. Hence, inferences related to their low level of knowledge regarding the risks imposed by the route of delivery are not possible. We can, however, state there is an urgent need for professionals who provide prenatal care to instruct women in regard to the differences between routes of delivery and the risks and benefits of each, so that women become aware and more capable of making conscious decisions.
In regard to the characteristics of the women, in this study, obstetrical history and type of previous delivery were associated with the type of delivery desired. In regard to number of pregnancies, one study ${ }^{22}$ did not report significant association with the outcome, a finding that contradicts the result found in this study. In regard to the type of the previous delivery, this variable was associated with the type of delivery preferred both in this and in another study. ${ }^{12}$ The experience of a previous delivery may motivate a woman's choice. Even though it is not possible to make inferences regarding this information, these associations may be related to the satisfaction of women with previous experiences. Another factor that demands attention is the type of delivery for first-time mothers, considering the influence of this first experience on their decisions concerning subsequent deliveries.

With regard to the mothers' age, a study reports that the proportion of births via C-section was from $60 \%$ to $70 \%$ among women older than 30 years of age, ${ }^{21}$ which may be related to fear as older women are more predisposed to risk during pregnancy. Age is seen as a risk factor for some morbidities during pregnancy and may be a relevant factor at the time women decide on the route of delivery, though such a conjecture cannot be confirmed. It is believed, however, that the quality of prenatal and obstetrical care provided to older expectant mothers should be more relevant than age per se.

Another study found significant statistical association between education and a preference for vaginal delivery, ${ }^{11}$ though such an association was not confirmed in this study. A higher level of education means having more information regarding the pregnancy cycle and birth process, so that more educated women are better able to make more appropriate choices. Another current study found that more than $80 \%$ of those with a high educational level had a C-section, ${ }^{21}$ which may be related to the fact that increased education is usually linked to increased buying power and the use of private services, which are known for higher rates of $\mathrm{C}$-sections.

Based on this study's findings, we believe that healthcare workers can be sensitized in regard to the need to expand educational resources with the objective to empower women during the pregnancy, ensuring them greater autonomy at the time of delivery.

These findings also reinforce the need to regain and strengthen the belief of women in their own bodies, capacities, and health conditions. It is important to reinforce orientation regarding the physiology of a birth, as well as its processes, as such information promotes women's self-knowledge and alleviates anxiety during labor. Therefore, obstetrical nurses play an important role as mediators in this educational process, strengthening the autonomy of women. Increased availability of continuing education to these professionals, as well as 
increasing the number of obstetrical nurses in Primary Care Units, is essential to obtaining quality prenatal care, with evidencebased guidance and actions, to improving the health conditions of pregnant women and to strengthening their autonomy during the pregnancy-puerperal cycle.

\section{CONCLUSION}

This study shows that most mothers preferred the vaginal route for delivery, especially those who already had a previous vaginal delivery. The reason most frequently reported by those who preferred a C-section was the pain of labor and better recovery postpartum was the reason reported by those who preferred a vaginal delivery.

Few women in this study were aware of the risks posed for themselves and their newborns by the type of labor they experienced. Additionally, most did not take part in decisionmaking regarding the type of delivery chosen. These results show a need to implement new practices in order to improve the autonomy of women and their ability to choose.

A significant association was found between the number of pregnancies and type oflprevious delivery with the type of delivery desired, which reinforces the importance of expanding educational programs during prenatal care to prevent the first delivery being by $\mathrm{C}$-section and also to improve the labor experiences of these women.

This study's findings reinforce the need for more educational programs directed to both healthcare workers and patients in order to empower them in regard to their bodies and enable them to make conscious choices at the time of delivery. In this context, we believe that obstetrical nurses have a unique role during the perinatal educational process and expanding their work can contribute to decreased asymmetry between the health staff and women under their care during labor.

The small number of papers addressing the variables considered in this study greatly restricted discussion regarding this topic. Another potential and important limitation was the fact that this study's participants had given birth very recently and, for this reason, their responses may have been influenced by their recent experiences along with stressful issues inherent to an immediate birth. Therefore, further studies are needed to provide other perspectives concerning the desires and knowledge of expectant mothers in regard to birth so that gradually a more solid understanding is acquired, capable of transforming the current scenario of care provided for labor and delivery.

\section{REFERENCES}

1. Pimentel TA, Oliveira-Filho EC. Fatores que influenciam na escolha da via de parto cirúrgica: uma revisão bibliográfica. Universitas: Ciênc Saúde [Internet]. 2016 Dec; [cited 2017 Jun 2]; 14(2):187-99. Available from: https://www.publicacoesacademicas.uniceub.br/cienciasaude/ article/viewFile/4186/3279. DOI: 10.5102/ucs.v14i2.4186
2. Sanfelice CFO, Abbud FSF, Pregnolatto OS, Silva MG, Shimo AKK. Do parto institucionalizado ao parto domiciliar. Rev RENE [Internet]. 2014 Mar/Apr; [cited 2014 May 10]; 15(2):362-70. Available from: http://www. revistarene.ufc.br/revista/index.php/revista/article/viewFile/1561/pdf DOI: 10.15253/2175-6783.2014000200022

3. Santos RAA, Melo MCP, Cruz DD. Trajetória de humanização do parto no Brasil a partir de uma revisão integrativa de literatura. Cad Cult Ciênc [Internet]. 2015 Mar; [cited 2017 Jan 2]; 13(2):76-89. Available from: http://periodicos.urca.br/ojs/index.php/cadernos/article/view/838/pdf_1 DOI: http://dx.doi.org/10.14295/cad.cult.cienc.v13i2.838

4. Rossignol M, Chaillet N, Boughrassa F, Moutquin JM. Interrelations between four antepartum obstetric interventions and cesarean delivery in women at low risk: a systematic review and modeling of the cascade of interventions. Birth [Internet]. 2014 Mar; [cited 2017 Jun 1]; 41(1):70-8. Available from: https://www.ncbi.nlm.nih.gov/pubmed/24654639. DOI 10.1111/birt.12088

5. Ministério da Saúde (BR). Secretaria Executiva. DATASUS: Sistema de Informação de Nascidos Vivos (SINASC) 2015. [cited 2017 May 28]. Available from: http://tabnet.datasus.gov.br/cgi/tabcgi.exe?sinasc/cnv/ pnvuf.def

6. Ministério da Saúde (BR). Secretaria de Vigilância em Saúde. Departamento de Análise de Situação em Saúde. Saúde Brasil 2013: uma análise da situação de saúde e das doenças transmissíveis relacionadas à pobreza. Brasília (DF): Ministério da Saúde; 2014 Available from: http://bvsms.saude.gov.br/bvs/publicacoes/saude_ brasil_2013_analise_situacao_saude.pdf

7. Reis TLR, Padoin SMM, Toebe TRP, Paula CC, Quadros JS. Autonomia feminina no processo de parto e nascimento: revisão integrativa da literatura. Rev Gaúcha Enferm [Internet]. 2017 Mar; [cited 2017 Jun 5]; 38(1):e64677. Available from: http://www.scielo.br/pdf/rgenf/ v38n1/0102-6933-rgenf-1983-144720170164677.pdf.DOI:http://dx.doi. org/10.1590/1983-1447.2017.01.64677

8. Silva ALS, Nascimento ER, Coelho EAC. Práticas de enfermeiras para promoção da dignificação, participação e autonomia de mulheres no parto normal. Esc Anna Nery [Internet]. 2015; [cited 2016 Apr 25]; 19(3):424-31. Available from: http://www.scielo.br/pdf/ean/v19n3/14148145-ean-19-03-0424.pdf. DOI: http://dx.doi.org/10.5935/14148145.20150056 .

9. Domingues RMSM, Dias MAB, Pereira MN, Torres JA, d'Orsi E, Pereira APE, et al. Processo de decisão pelo tipo de parto no Brasil: da preferência inicial das mulheres à via de parto final. Cad Saúde Pública [Internet]. 2014; [cited 2014 May 20]; 30(Supl.1):S101-16. Available from: http://www.scielo.br/pdf/csp/v30s1/0102-311X-csp-30-s1-0101. pdf. DOI: http://dx.doi.org/10.1590/0102-311X00105113.

10. Yee LM, Kaimal AJ, Houston KA, Wu E, Thiet MP, Nakagawa S, et al. Mode of delivery preferences in a diverse population of pregnant women. Am J Obstet Gynecol [Internet]. 2015 Mar; [cited 2015 May 30]; 212(3):377.e1-24. Available from: http://www.ncbi.nlm.nih.gov/ pubmed/25446662. DOI: 10.1016/j.ajog.2014.10.029

11. Benute GRG, Nomura RY, Santos AM, Zarvos MA, Lucia MCS, Francisco RPV. Preferência pela via de parto: uma comparação entre gestantes nulíparas e primíparas. Rev Bras Ginecol Obstet [Internet]. 2013; [cited 2016 Nov 15]; 35(6):281-5. Available from: http://www.scielo.br/pdf/rbgo/v35n6/ v35n6a08.pdf.DOl:http://dx.doi.org/10.1590/S0100-72032013000600008

12. Vale LD, Lucena EES, Holanda CSM, Cavalcante RD, Santos MM. Preferência e fatores associados ao tipo de parto entre puérperas de uma maternidade pública. Rev Gaúcha Enferm [Internet]. 2015 Sep; [cited 2015 Nov 30]; 36(3):86-92. Available from: http://www. scielo.br/scielo. php? pid=S1983-14472015000300086\&script=sci arttext\&tlng=pt. DOI: http://dx.doi.org/10.1590/1983-1447.2015.03

13. Leguizamon Junior T, Stefani JA, Bonamigo EL. Escolha da via de parto: expectativa de gestantes e obstetras. Rev Bioét. 2013;21(3):509-17.

14. Seelmamm HT, Santos JO, Shimo AKK. Opinião de estudantes de nutrição sobre a preferência pela via de parto. Rev Enferm Aten Saúde. [Internet]. 2013; [cited 2015 Jul 2]; 2(1):60-74. Available from: http://seer uftm.edu.br/revistaeletronica/index.php/enfer/article/view/306/389. DOI: http://dx.doi.org/10.18554/ 
15. World Health Organization - WHO. Department of Reproductive Health \& Research. Care in normal births: a practical guide [Internet]. Geneva:World Health Organization; 1996 [cited 2016 Jan 14]. Available from: http://apps.who.int/iris/bitstream/10665/63167/1/WHO_FRH_ MSM_96.24.pdf

16. Sodré TM, Merighi MAB, Bonadio ICE. Escolha informada no parto: um pensar para o cuidado centrado nas necessidades da mulher. Ciênc Cuid Saúde [Internet]. 2012; [cited 2015 May 20]; 11(Supl):115-20. Available from: http://periodicos.uem.br/ojs/ index.php/CiencCuidSaude/article/view/17062/pdf. DOI: 10.4025/ cienccuidsaude.v10i5.17062

17. Cook K, Loomis C. The Impact of Choice and Control on Women's Childbirth Experiences. J Perinat Educ [Internet]. 2012; [cited 2015 Dec 24]; 21(3):158-68. Available from: https://www.ncbi.nlm.nih.gov/ pmc/articles/PMC3392605/pdf/JPE21-3_PTR_A5_158-168.pdf.DOI: 10.1891/1058-1243.21.3.158

18. Ferraz L, Bordignon M. Mortalidade materna no Brasil: uma realidade que precisa melhorar. Rev Baiana Saúde Pública [Internet]. 2012; [cited 2016 Jun 12]; 36(2):527-38. Available from: http://files.bvs.br/ upload/S/0100-0233/2012/v36n2/a3253.pdf
19. Reis ZSN, Lage EM, Aguiar RALP, Gaspar JS, Vitral GLN, Machado EG Associação entre risco gestacional e tipo de parto com as repercussões maternas e neonatais. Rev Bras Ginecol. Obstet. [Internet]. 2014; [cited 2015 Dec 10]; 36(2):65-71. Available from: http://www.scielo.br/ pdf/rbgo/v36n2/0100-7203-rbgo-36-02-00065.pdf. DOI: http://dx.doi. org/10.1590/S0100-72032014000200004

20. Lansky S, Friche AAL, Silva AAM, Campos D, Bittencourt SDA, Carvalho ML, et al. Pesquisa Nascer no Brasil: perfil da mortalidade neonatal $e$ avaliação da assistência à gestante e ao recém-nascido. Cad Saúde Pública [Internet]. 2014; [cited 2015 May 30]; 30(Supl):S192-207. Available from: http://www.scielo.br/pdf/csp/v30s1/0102-311X-csp30-s1-0192.pdf. http://dx.doi.org/10.1590/0102-311X00133213

21. Rattner D, Moura EC. Nascimentos no Brasil: associação do tipo de parto com variáveis temporais e sociodemográficas. Rev Bras Saúde Mater Infant [Internet] 2016 Jan/Mar; [cited 2016 May 30]; 16(1):3947. Available from: http://www.scielo.br/scielo.php?script=sci_arttex t\&pid=S1519-38292016000100039. http://dx.doi.org/10.1590/180693042016000100005

22. Dweik D, Girasek E, Töreki A, Mészáros G, Pál A. Women's antenatal preferences for delivery route in a setting with high cesarean section rates and a medically dominated maternity system. Acta Obstet Gyneco Scand [Internet]. 2014 Apr; [cited 2016 Jan 26]; 90(4):408-15. Available from: http://dx.doi.org/10.1111/aogs.12353 